\title{
$\beta$-lactamase Induction in Nosocomial Staphylococcus aureus Strains Cultured from the Nasal Cavity and Wound of Patients
}

\author{
Nkem Torimiro ${ }^{1} \&$ Olusayo T, Olutola ${ }^{1}$ \\ ${ }^{1}$ Department of Microbiology, Obafemi Awolowo University Ile-Ife, Nigeria \\ Correspondence: Nkem Torimiro, Department of Microbiology, Obafemi Awolowo University Ile-Ife, Nigeria. \\ E-mail: ntorimiro@gmail.com
}

Received: November 23, 2017

Accepted: December 19, 2017 Online Published: December 28, 2017

doi:10.5539/ijb.v10n1p24

URL: https://doi.org/10.5539/ijb.v10n1p24

\begin{abstract}
The study was conducted to determine $\beta$-lactamase induction in Staphylococcus aureus strains cultured from the nasal cavity and surgical wounds of in- patients at a tertiary teaching hospital.

Swab samples were taken from the nasal cavity -wound pair of 110 consented patients. The $S$. aureus isolates were identified and the antibiotics susceptibility tests were conducted using standard protocols. $\beta$-lactamase induction was assayed with the micro-iodometric method. The data obtained were statistically analysed.

A total of $81 \mathrm{~S}$. aureus isolates were cultured from the nasal cavity and wounds of the 110 samples collected. $\beta$-lactamase was produced by $14(41.2 \%)$ and $26(55.3 \%)$ of the isolates cultured from the nasal cavity and wounds respectively. Constitutive and induced $\beta$-lactamase production was observed.

$\beta$-lactamase production in the isolates is not dependent on antibiotic exposure alone. The findings underscore the need for appropriate infection control and adequate hygiene practices to prevent the spread of $S$. aureus in the hospital settings.
\end{abstract}

Keywords: Antibiotics, $\beta$-lactam, $\beta$-lactamase, Induction, nasal cavity, resistance, Staphylococcus aureus, Wounds

\section{Introduction}

The human skin acts as an excellent barrier to infection but if this barrier is breached, microorganisms regarded as commensals on body surface may assume the role of opportunist pathogens. Wound is caused as a result of a breach in the intact skin and wound infections are an important cause of morbidity and account for $70-80 \%$ mortality in the hospital setting (Wilson et al., 2004; Gottrup, Melling, Hollander, 2005). The risk of developing surgical wound infection and the severity of complications depend mainly on the number of pathogens and site of infection (Dohmen, Gabbieri, Weymann, Linneweber \& Konertz., 2009). It has been observed that $S$. aureus is the most common organism isolated from wound and is the leading cause of bloodstream, lower respiratory tract, skin/soft tissue infections in all body regions (Lowy, 1998; Gordon and Lowy, 2008). A study carried out by Emele, Izomoh \& Alufohai (1999) revealed that $S$. aureus is the most frequently isolated organism in wound infection in post-operative sepsis. Gayathree and Deshpande (2011), Vijayalakshmi (2012) in their study on surgical site infections observed $S$. aureus as the most common organism isolated from surgical site infection.

Apart from the organism being an important and virulent nosocomial pathogen, it has been reported that the organism possesses the propensity to resist the action of a plethora of antimicrobial agents (Archer, 1998; Cooper et al., 2004; Torimiro, Moshood \& Eyiolawi., 2013). Beta-lactam antimicrobial agents are the preferred drugs in the treatment of $S$. aureus infections. They exhibit their bactericidal effects by inhibiting enzymes involved in cell wall synthesis. The integrity of the bacterial cell wall is essential to maintaining cell shape in a hypertonic and hostile environment (Massova and Mobashery, 1998). However, reports have shown that resistance to $\beta$-lactam antibiotics is rampant. (Francis, Harold, Roger, \& David, 1997; Schito, 2006; Torimiro et al., 2013).

Beta-lactamase is the most prevalent mechanism of bacterial resistance to $\beta$-lactam antibiotics and have been documented to have co-evolved with them since their introduction into clinical use (Medeiros, 1997; Rice \& Bonomo, 2000). Staphylococcal $\beta$-lactamase is not chromosomal and is carried on plasmids and can be non-inducible or inducible with antibiotic contact (Maddux, 1991). This enzyme inactivates the $\beta$-lactam antibiotics (penicillin) by cleavage of the beta-lactam ring. Incidence of $\beta$-lactamase production in $S$. aureus 
observed to be over $80 \%$ has been documented (Parker \& Collier, 1990; Schito, 2006; Akindele, Adedokun \& Olaolu, 2010; Torimiro et al., 2013).

The induction of $\beta$-lactamase synthesis is important for the resistance of staphylococci to penicillins since the drug both induces synthesis of the enzyme and is hydrolysed by it. Many new $\beta$-lactam antibiotics have been developed that were specifically designed to be resistant to the hydrolytic action of $\beta$-lactamases. However, with each new class that has been used to treat patients, $\beta$-lactamases emerged that caused resistance to that class of drug. In addition, $\beta$-lactamase has been reported to spread to most clinical isolates of $\mathbf{S}$. aureus as well as other species of staphylococci (Bradford, 2001).

S. aureus colonises the nasal mucosa of approximately $25-30 \%$ of apparently healthy population (Lamikanra, Paul, Akinwole, Paul, 1985; Yamamoto et al., 2010). This provides a reservoir from which it can be introduced when host defenses are breached, and has been reported to increase the risk for subsequent infections (Mahdi et al., 2000; Wertheim et al., 2005). Although this may depend on an array of factors that may either be environmental or patient-related. This study aims to determine antibiotic susceptibility pattern and evaluate the induction of $\beta$-lactamase in S. aureus isolates

\section{Materials and Methods}

\subsection{Study Population}

Nasal and wound swabs were collected from one hundred and ten $>48 \mathrm{~h}$ hospitalized surgical wound patients at the Obafemi Awolowo University Teaching Hospitals Complex (OAUTHC), Ile-Ife, Osun-State, Nigeria after due informed consent and ethical clearance were obtained.

\subsection{Isolation and Identification of the Isolates}

The nasal and wound samples were collected using sterile tipped applicators. The samples were transported immediately to the Microbiology Laboratory and processed within four hours of collection. The specimens were inoculated into nutrient broth (Lab M, USA) and incubated at $37^{\circ} \mathrm{C}$ for $24 \mathrm{~h}$. The cultures were streaked onto mannitol salt agar (MSA) and incubated at $37^{\circ} \mathrm{C}$ for $18-24 \mathrm{~h}$. The isolates were characterised using standard microbiological methods as described (Cheesbrough, 2006). Also the latex agglutination test using Pastorex Staph-Plus (Bio-Rad, USA) was done and the isolates were identified as $S$. aureus (Holt, Krieg, Sneath, Stanley \& Williams, 1994).

\subsection{Antibiotic Susceptibility Typing and $\beta$-Lactamase Test}

Antibiotic susceptibility of the S.aureus isolates was done using by Kirby-Bauer disk diffusion method. The impregnated antibiotics discs of known concentrations includes amoxicillin $(25 \mu \mathrm{g})$, augmentin $(30 \mu \mathrm{g})$, cloxacillin $(5 \mu \mathrm{g})$ (Abtek Biologicals, UK) while cefoxitin $(30 \mu \mathrm{g})$, ceftriaxone $(30 \mu \mathrm{g})$, imipenem $(10 \mu \mathrm{g})$, oxacillin ( $1 \mu \mathrm{g})$, penicillin $\mathrm{G}(10 \mathrm{U})$ (Oxoid, UK). The interpretation of the zone of inhibition was done according to the recommendations of the Clinical and Laboratory Standards Institute (2009) and AB biodisk interpretation chart. Intermediate resistance was recorded as resistant.

Acidometric agar plate method for $\beta$-Lactamase detection were conducted as described Park, Lopez \&Cook (1978) as reported in Olutola, Adeyanju \& Torimiro (2016).

\section{$2.4 \beta$-Lactamase Induction Test}

The induction of $\beta$-Lactamase was carried out using a modified method as described by Kraft, Prabhu, Ursinus \& Höltje (1999). Cells (1 ml) from the exponential growth phase in nutrient broth were diluted with $1 \mathrm{ml}$ of nutrient broth (medium) containing 1-8 $\mu \mathrm{g} / \mathrm{ml}$ of cefoxitin and penicillin in separate tubes. The mixture was incubated at $37^{\circ} \mathrm{C}$ for $30 \mathrm{~min}$. Control samples received medium without cefoxitin and penicillin.

After $30 \mathrm{~min}$ incubation, the cells were spun down at $13,500 \mathrm{rpm}$ for $20 \mathrm{~min}$ at $4^{\circ} \mathrm{C}$ in a centrifuge. The spun cells were washed once with $50 \mathrm{mM}$ sodium phosphate buffer ( $\mathrm{pH} 7.0$ ), re-suspended in $1 \mathrm{ml}$ of the same buffer and stored in at $4^{\circ} \mathrm{C} .20 \mu \mathrm{l}$ of the resuspended cells was treated with $20 \mu \mathrm{l}$ of lysis buffer [ $400 \mathrm{mM}$ Tris- $\mathrm{HCl}, 8 \mathrm{mM}$ EDTA, $200 \mu \mathrm{g} / \mathrm{ml}$ of lysozyme ( $\mathrm{pH} \mathrm{8.0)]} \mathrm{and} 40 \mu \mathrm{l}$ of distilled water, followed by 15 min incubation at room temperature. The protein concentration of the lysate was determined by the Lowry's method (Lowry, Rosebrough, Farr \& Randall, 1951). Bovine Serum Albumin (Sigma) was used as the protein standard and the absorbance of the samples at $\mathrm{A}_{660 \mathrm{~nm}}$. were read using a spectrophotometer (Cintral, Australia).

\subsubsection{Quantification of the Lactamase Activity}

Modified micro-iodometric assay for the quantification of lactamase activity according to Novick (1962) as reported by Sykes \& Nordstrom (1972) was used. A $0.089 \mathrm{~g}$ of benzyl penicillin was dissolved in $100 \mathrm{ml}$ of phosphate buffer $(\mathrm{pH} 7.2,0.1 \mathrm{M})$ and the mixture was placed on ice (substrate solution). 
Exactly $1 \mathrm{ml}$ starch-iodine solution and $0.9 \mathrm{ml}$ of $50 \mathrm{mM}$ phosphate buffer were mixed in test tubes. Observation of blue colour indicated the reaction of iodine with starch. Exactly $1 \mathrm{ml}$ benzyl penicillin solution (substrate solution) on ice was added to the mixture in test tubes at the point of assay. Sample solution $(0.1 \mathrm{ml})$ was introduced into a glass cuvette and thereafter, the mixture in the test tube was added to the sample solution in the glass cuvette which made up to $2.9 \mathrm{ml}$. The spectrophotometer was left for $5 \mathrm{~min}$ for the temperature to reach $30^{\circ} \mathrm{C}$ and blank with phosphate buffer (control solution) at $\mathrm{A}_{620 \mathrm{~nm}}$ before the reaction was initiated. Absorbance at $\mathrm{A}_{620 \mathrm{~nm}}$ was then read at $30 \mathrm{~s}$ interval for $5 \mathrm{~min}$. Rapid decolourization indicated $\beta$-lactamase production.

Units of $\beta$-Lactamase: One unit of $\beta$-lactamase is defined as the amount of enzyme that hydrolyzes benzyl penicillin at the rate of $1 \mu \mathrm{mole} / \mathrm{min}$ (Sykes \& Nordstrom, 1972; Karmakar, Dua \& Ghosh, 2016).

\section{Results}

\subsection{Antibiotic Susceptibility Profile of the S. aureus Isolates}

Eighty-one (73.6\%) S. aureus strains were isolated from the nasal-wound pair of 110 wound patients. All of the 34 $(42 \%)$ isolates cultured from the nasal swabs were resistant to amoxicillin, augmentin and cloxacillin but only 1 (2.9\%) was resistant to imipenem (Table 1 ).

Forty-seven (58\%) of the isolates were cultured from wounds and the antibiotics susceptibility profile as observed by Olutola et al. (2016) are as shown (Table 1).

Table 1. Antibiotic Susceptibility Profile of the Staphylococcus aureus strains Isolated from the nasal and wound pair

\begin{tabular}{|c|c|c|c|c|c|c|}
\hline Antibiotics & Nasal Isolates & $\begin{array}{l}\text { Antibiotic profile } \\
\text { S }\end{array}$ & $\begin{array}{l}\text { Freq (\%) } \\
R\end{array}$ & Wound Isolates & $\begin{array}{l}\text { Antibiotic profile } \\
\text { S }\end{array}$ & $\begin{array}{l}\text { Freq (\%) } \\
R^{2}\end{array}$ \\
\hline Amoxycillin & & 0 & $34(100)$ & & 0 & 47 (100) \\
\hline Augmentin & & 0 & $34(100)$ & & $13(27.7)$ & $34(72.3)$ \\
\hline Cefoxitin & 34 & $8(23.5)$ & $26(76.5)$ & 47 & $11(23.4)$ & $36(76.6)$ \\
\hline Ceftriaxone & & $18(52.9)$ & $16(47.1)$ & & $20(42.6)$ & $27(57.4)$ \\
\hline Cloxacillin & & 0 & $34(100)$ & & 0 & 47 (100) \\
\hline Imipenem & & $33(97.1)$ & $1(2.9)$ & & $42(89.4)$ & $5(10.6)$ \\
\hline Oxacillin & & $3(8.8)$ & 31 (91.2) & & $4(8.5)$ & $43(91.5)$ \\
\hline Penicillin & & $1(2.9)$ & $33(97.1)$ & & 0 & $47(100)$ \\
\hline
\end{tabular}

Note, $\mathrm{R}=$ Resistance, $\mathrm{S}=$ Susceptible.

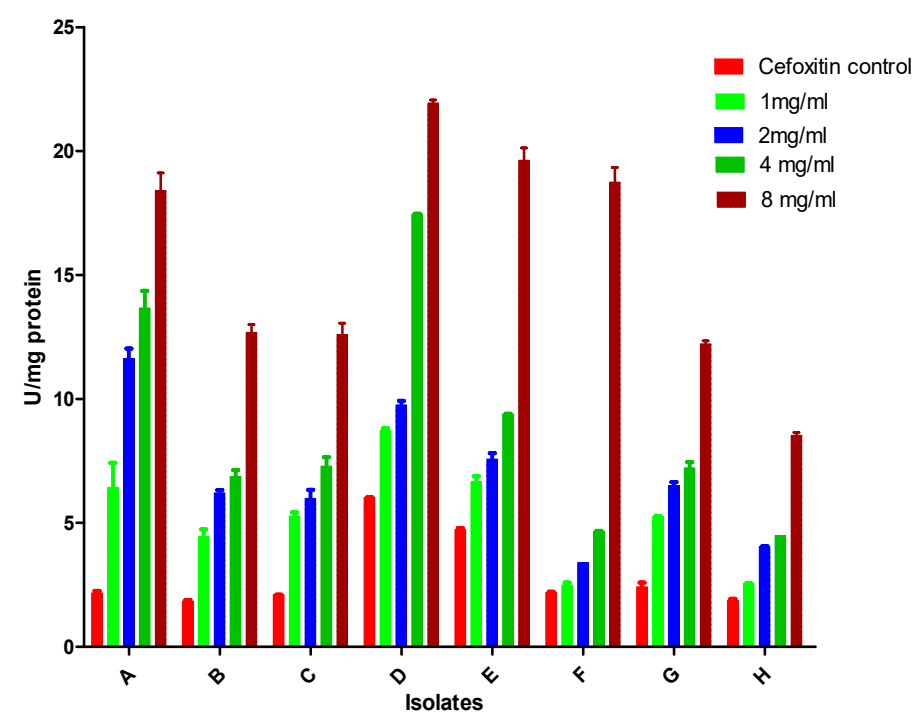

Figure 1. $\beta$ - lactamase induction of Isolates at varied Cefoxitin Concentration

The rate of $\beta$ - lactamase induction in isolates A- C S. aureus cultured from the nasal swab. D-G isolates from wound swabs increases with increase in concentration of cefoxithin; $\mathrm{H}=$ control strain 


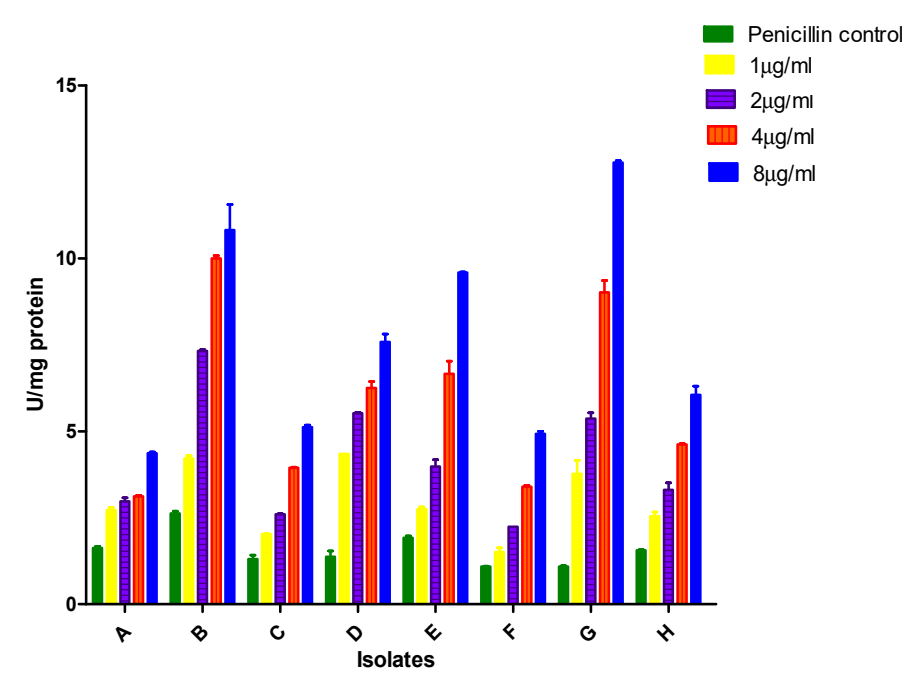

Figure 2. $\beta$ - lactamase induction of Isolates at varied Penicillin Concentration

The rate of $\beta$ - lactamase induction in isolates A- C S. aureus cultured from the nasal swab. D-G isolates from wound swabs increases with increase in concentration of cefoxithin; $\mathrm{H}=$ control strain

\subsection{Effect of Concentration of $\beta$-Lactam Antibiotics to $\beta$-Lactamase Induction}

Beta-lactamase production was detected in 48 (59.3\%) of the 81 S. aureus strains isolated from the nasal cavity and wounds. Production of $\beta$-lactamase enzyme was observed before the addition of inducer but it was generally observed that the rate of induction increased with increase in antibiotic concentration with both cefoxitin and penicillin antibiotics respectively as shown (Figures 1 and 2).

\section{Discussion}

The prevalence of $S$. aureus recovered from the wound and nasal mucosa was $58 \%$ and $42 \%$ respectively. Surgical site infection by $S$. aureus has been observed to be at $45.2 \%$ prevalence rate in a study conducted in India (Vijayalashim, 2012). The study revealed a high resistance to penicillin and other $\beta$-lactams by the $S$. aureus strains which is in agreement with previous studies (Esan, Famurewa, Lin \& Shittu, 2009; Akindele et al., 2010). The resistance of $S$. aureus strains to $\beta$-lactams which are the most commonly used antibiotics is well documented.

The production of $\beta$-lactamase observed in this study was $49.4 \%$ in both wound and nasal $S$. aureus strains but lower compared to previous studies in which $70-80 \%$ was reported (Akindele et al., 2010; Torimiro et al., 2013). This difference may be as a result of the collection of samples from limited specimens compared to the previous investigators who collected samples from various clinical specimens. Staphylococcal $\beta$-lactamase is not chromosomal and is carried on plasmids and can be non-inducible or inducible with antibiotic contact (Maddux, 1991). This present study revealed that the production of enzyme is both constitutive and inductive which may imply that the production of the enzyme could be an intrinsic defence of the organisms against the action of antibiotics or as a result of use of the antibiotics.

The production of $\beta$-lactamase enzyme in this study was noticed before the addition of inducer (antibiotic) but it was observed that the specific activity of $\beta$-lactamase increased with increase in antibiotic concentration. The result supports the findings of (Nordstrom \& Sykes, 1973; Okonogi, Kuno,\& Higashide, 1986; Raimondi, Sisto \& Nikaido, 2007) who reported that the specific activity of $\beta$-lactamase increased linearly with increasing concentrations of inducer. In addition, Khan, Sallum, Zheng, Nau \& Hassan (2014) in their study on rapid determination of $\beta$-lactamase and antibiotic activity detected $\beta$-lactamase in the absence of inducer however, at a lower level when compared with induction.

In conclusion, it was observed that the $S$. aureus isolates were resistant to the various antibiotics tested. It was also shown in this study, that $\beta$ - lactamase production could be induced and constitutive indicating the need for improvement in infection control strategies in the hospital settings in order to reduce over dependence on antibiotics for treatment and transmission of resistant strains. In addition, there is need for the development of new classes of antibiotics to treat infections caused by S. aureus strains. 


\section{Competing Interest}

The Authors declare there is no competing interest.

\section{Acknowledgement.}

The Authors are grateful to the patients for their cooperation and Mr. A. Adeyanju for his kind assistance.

\section{References}

Akindele, A. A., Adewuyi, I. K., Adefioye, O. A., Adedokun, S. A., \& Olaolu, A. O. (2010). Antibiogram and Beta-Lactamase Production of Staphylococcus aureus Isolates from Different Human Clinical Specimens in a Tertiary Health Institution in Ile-Ife, Nigeria. American. Eurasian Journal of Scientific Research, 5(4), 230-233.

Archer, G. L. (1998). Staphylococcus aureus: A well-armed pathogen. Clinical Infectious Diseases, 26, 1179-1181.

Bradford, P. A. (2001). Extended-Spectrum $\beta$-Lactamases in the 21st Century: Characterization, Epidemiology and Detection of This Important Resistance Threat. Clinical Microbiology Reviews, 14(4), 933-951. https://doi.org/10.1128CMR)14.4.933-951.2001

Cheesbrough, M. (2006). District Laboratory Practice in Tropical Countries Part 2 (2nd ed.). Cambridge University Press, New York.

Clinical and Laboratory Standards Institute CLSI/NCCLS. (2009). Performance standards for antimicrobial susceptibility testing. Nineteen Information Supplement 29:3. CLSI/NCCLS document M100-S19, Wayne, Pennsylvania.

Cooper, B. S., Medley, G. F., Stone, S. P., Kibbler, C. C., Cookson, B. D., Roberts, J. A., ... Ebrahim, S. (2004). Methicillin-resistant Staphylococcus aureus in hospitals and the community: Stealth dynamics and control catastrophes. Proceedings of the National Academy of Sciences, 101(27), 10223-10238.

Dohmen, P. M., Gabbieri, D., Weymann, A., Linneweber, J., \& Konertz, W. (2009). Reduction in surgical site Infection in patients treated with microbial sealant prior to coronary artery bypass graft surgery: A case-control study. Journal of Hospital Infection, 72(2), 119-126. https://doi.org/10.1016/j.jhin.2009.02.005

Dryden, M. S. (2009). Skin and soft tissue infection: microbiology and epidemiology. International Journal of Antimicrobial Agents, 34(1), S2-S7. https//doi.org/10.1016/S0924-8579(09) 70541-2

Dyke, K. G. H., \& Gregory, P. D. (1996). Resistance to beta-lactam antibiotics: resistance mediated by beta-lactamase, Crossley, K.B., Archer, G.L. (eds.). The Staphylococci in Human Disease (1st ed.). Churchill Livingstone 136-157.

Emele, F. E., Izomoh, M. I., \& Alufohai, E. (1999). Microorganisms associated with wound infections in Ekpoma Nigeria. West African Journal of Medicine, 18(2), 97-100.

Esan, C. O., Famurewa, O, Lin, J., \& Shittu, A. O. (2009). Characterization of Staphylococcus aureus isolates obtained from health care institutions in Ekiti and Ondo States, South-Western Nigeria. African Journal of Microbiology Research, 3(12), 962-968. Article Number- 9529F0515088

Francis, O., Harold, L. P., Roger, F. G., \& David, G. (1997). Antibiotic and Chemotherapy (7th ed.). Churchill Livingston, U.K..

Gayathree, N., \& Deshpande, S. R. (2011). A Study on Surgical Site Infections Caused by Staphylococcus aureus with a Special Search for Methicillin-Resistant Isolates. Journal of Clinical Diagnostic Research, 5(3), 502-508.

Gordon, R. J. \& Lowy, F. D. (2008). Pathogenesis of Methicillin-Resistant Staphylococcus aureus Infection. Clinical Infectious Disease. 46(5), S350-S359. https//doi.org/10.1086/533591

Gottrup, F., Melling, A., \& Hollander, D. (2005). An overview of surgical site infections: aetiology, incidence and risk factors. European Wound Management. Association. Journal, 5(2), 11-15. http://www.worldwidewounds.com/2005

Holt, J. G., Krieg, N. R., Sneath, D. H. A., Stanley J. T., \& William S. T. (1994). Bergey's Manual of Determinative Bacteriology (9th ed.). The Williams and Wilkins company Baltimore USA. 
Karmakar A., Dua, P., \& Ghosh C. (2016) Biochemical and Molecular Analysis of Staphylococcus aureus clinical Isolates from Hospitalized Patients. Canadian Journal of Infectious Disease and Medical Microbiology, 2016, 7. http://dx.doi.org/10.1155/2016/9041636

Khan, S., Sallum, U. W., Zheng, X., Nau, G. J. \& Hasan, T. (2014). Rapid optical determination of $\beta$-lactamase and antibiotic activity. BMC Microbiology, 14, 84. https://doi.org/10.1186/1471-2180-14-84.

Kraft, A. R., Prabhu, J., Ursinus, A., \& Höltje, J. V. (1999). Interference with Murein Turnover Has No Effect on Growth but Reduces $\beta$-Lactamase Induction in Escherichia coli. Journal of Bacteriology, 181(23), 7192-7198.

Lamikanra, A., Paul, B. D., Akinwole, O. B., \& Paul, M. O. (1985). Nasal carriage of Staphylococcus aureus in a population of healthy Nigerian students. Journal of Medical Microbiology, 19, 211-216.

Lowry, O. H., Rosebrough, N. J., Farr, A. L., \& Randall, J. R. (1951). Protein measurement with the folin phenol reagents. Journal of Biology and Chemistry, 193, 265-275.

Lowy, F. D. (1998). Staphylococcus aureus infections. New England Journal of Medicine, 339, 520-532. https//doi.org/10.1056/NEJM199808203390806

Maddux, M. S. (1991). Effects of beta-lactamase-mediated antimicrobial resistance: the role of beta-lactamase inhibitors. Pharmacotherapy, 11(2), 40S-50S.

Mahdi, S. E. I., Ahmed, A. O. A., Boelens, H., Ott, A., Abugroun, E. S., van Belkum, A.,... Fahal, A. (2000). An epidemiological study of the occurrence of Staphylococcus aureus in superficial abscesses of patients presenting for surgery in a teaching hospital in Khartoum, Sudan. FEMS Immunology and Medical Microbiology, 29, 155-162.

Massova, I., \& Mobashery, S. (1998). Kinship and diversification of bacterial penicillin-binding proteins and $\beta$-lactamases. Antimicrobial Agents and Chemotherapy, 42, 1-17.

Medeiros, A. A. (1997). Evolution and dissemination of $\beta$-lactamases accelerated by generations of $\beta$-lactam antibiotics. Clinical Infectious Diseases, 24(1), S19-S45.

Nordstrom, K., \& Sykes, R.B. (1973). Effects of sublethal concentrations of benzylpenicillin on Pseudomonas aeruginosa. Antimicrobial Agents and Chemotherapy, 6, 641-646.

Novick, R. P. (1962). Microiodometric assay for penicillinase. Biochemistry Journal, 83, 236-240.

Okonogi, K., Kuno, M., \& Higashide, E. (1986). Induction of $\beta$-Lactamase in Proteus vulgaris. Journal of General Microbiology, 132, 143-150.

Olutola, O. T., Adeyanju, A., \& Torimiro, N. (2016). Extended spectrum $\beta$-lactamase detection and antibiotic susceptibility profile of Staphylococcus aureus strains isolated from surgical wounds. British Microbiology Research Journal, 17(5), 1-7. https//doi: 10.9734/BMRJ/2016/27848

Park, C. H., Lopez, J. S., \& Cook, C. B. (1978). Acidometric agar plate method for ampicillin susceptibility testing of Haemophilus influenza. Antimicrobial Agents and Chemotherapy, 13, 318-320.

Parker, M. T., \& Collier, L. H. (1990). Topley and Wilson's Principles of Bacteriology, Virology and Immunity, 8th Edition.Vol.2 and 3. Edward Arnold, a Division of Hodder and Stouthon, Mill Rd, Dunton Green, Seven Oaks, Kent TN13 2YA by Butter and Tanner Ltd., Frome and London, pp. 162-185 (Vol.2), pp.2-237 (Vol.3).

Raimondi, A., Sisto, F., \& Nikaido, H. (2001). Mutation in Serratia marcescens AmpC beta-Lactamase producing high-Level Resistance to Ceftazidime and Cefpirome. Antimicrobial Agents and Chemotherapy, 45, 2331-2339.

Rice, L. B., \& Bonomo, R. A. (2000). Beta-lactamases, which ones are clinically important. Drugs Resistant Update, 3, 178-189.https://doi.org/ 10.54/drup.2000.0144

Schito, G. C. (2006). The importance of the development of antibiotic resistance in Staphylococcus aureus. Clinical Microbiology and Infection, 12(1), 3-8.

Sykes, S. R. B. \& Nordstrom, K. (1972). Microiodometric Determination of $\beta$-Lactamase Activity. Antimicrobial Agents Chemotherapy, 1(2), 94-99.

Torimiro, N., Moshood, A. A., \& Eyiolawi, S. A. (2013). Analysis of Beta-lactamase production and Antibiotics resistance in Staphylococcus aureus strains. Journal of Infectious Diseases and. Immunity, 5(3), 24-28. https://doi 10.5897/JIDI2013.0118. 
Vijayalakshmi, P. (2015). Incidence of Staphylococcus aureus in surgical site infections in a teaching hospital, Inter. Journal of Current Microbiology and Applied Sciences, 4, 32-54.

Wertheim, H. F., Melles, D. C., Vos, M. C., van Leeuwen, W., vanBelkum, A., Verbrugh, H. A., \& Nouwen, J. L. (2005). The role of nasal carriage in Staphylococcus aureus infections. Lancet Infectious Disease, 5,751-762.

Wilson, A. P. R., Gibbons, C., Reeves, B. C., Hodgson, B., Liu, M. Plummer, D., ... Pearson, A. (2004). Surgical wound infections as a performance indicator: agreement of common definitions of wound infections in 4773 Patients.

Yamamoto, T., Nishiyama, A., Takano, T., Yabe, S., Higuchi, W., Razvina, O., \& Shi, D. (2010). Community-acquired methicillin-resistant Staphylococcus aureus: Community transmission, pathogenesis and drug resistance. Journal of Infection and Chemotherapy. 16(4), 225-254. https://doi.org/10.1007/ s10156-010-0045-9.

\section{Copyrights}

Copyright for this article is retained by the author(s), with first publication rights granted to the journal.

This is an open-access article distributed under the terms and conditions of the Creative Commons Attribution license (http://creativecommons.org/licenses/by/4.0/). 